\title{
Specific neural representation for a conceptual set of behavior: pair bonding [Corrigendum]
}

\author{
Dios AM, Alexander K, Hanson SJ, Cheng MF. Research \\ and Reports in Biology. 2013:4 33-38.
}

On page 1, Abstract, first sentence,

"Our study examines whether ZENK expression in the nucleus taeniae (avian amygdala) serves as a predictor for pair bonding in ring doves." Should read as

"Our study examines whether ZENK expression in the nucleus taeniae (avian amygdala) serves as a predictor for pair bonding in ring doves (Streptoplia risoria)."

On page 1, Introduction, 2nd sentence,

"Aside from aiding male parental care, ${ }^{1}$ a pair bond functions in insuring paternity ${ }^{1}$ and in aiding provisioning (Schwagmeyer and Mock D)." Should read as

"Aside from aiding male parental care, ${ }^{1}$ a pair bond functions in insuring paternity and in aiding provisioning. ${ }^{1-4}$ "

On page 34, under the heading "Stimulus preference test", the sentence,

"Doves in both groups were put through a y-shaped preference test developed by our laboratory (Figure 1).” Should read as

"Doves in both groups were put through a y-shaped preference test developed by our laboratory (Figure 1). ${ }^{26}$ "
On page 34, fifth paragraph, first sentence,

"In experiment 1 , we looked at whether ZENK counts in the taeniae were able to classify both male and female doves as pair bonded or not." Should read as

"In experiment 1, we looked at whether ZENK counts in the taeniae were able to classify both male and female ring doves (Streptoplia risoria) as pair bonded or not."

On page 37 , second paragraph in the right column, first sentence,

"The taeniae is ideally connected for behaviors associated with reproductive strategies via various distinct regions of the archistriatum, the nucleus accumbens, and other areas responsible for visual and olfactory input (Cheng et al 1999). ${ }^{21}$ " Should read as

"The taeniae is ideally connected for behaviors associated with reproductive strategies via various distinct regions of the archistriatum, the nucleus accumbens, and other areas responsible for visual and olfactory input. ${ }^{21 "}$

Reference 6, "Marazziti D, Dell'Osso B, Baroni S, et al. A relationship between oxytocin and anxiety of romantic attachment. Clin Pract Epidemiol Ment Health. 2006;2:28.", should have been deleted. All citations in the text, from reference 6 should have been renumbered accordingly.

Research and Reports in Biology

\section{Publish your work in this journal}

Research and Reports in Biology is an international, peer-reviewed, open access journal publishing original research, reports, editorials, reviews and commentaries on all areas of biology including animal biology, biochemical biology, cell biology, ecological studies,

manuscript management system is completely online and includes a very quick and fair peer-review system. Visit http://www.dovepress. $\mathrm{com} /$ testimonials.php to read real quotes from published authors. 